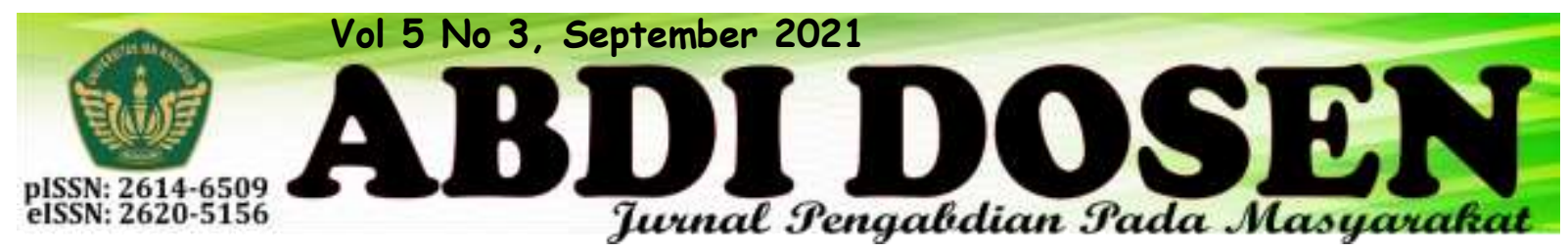

\title{
SOSIALISASI KESEHATAN PENCEGAHAN COVID 19 DI KELURAHAN MARGASARI KOTA BALIKPAPAN
}

\author{
Hairul Anam \\ hairul@uniba-bpn.ac.id \\ Fakultas Ekonomi, Universitas Balikpapan
}

\begin{abstract}
Health outreach activities for the prevention of Covid 19 are community service activities in an effort to contribute to society to meet the needs of life and solve problems experienced by the community, especially in preventing the transmission of Covid-19. This activity is carried out through the Covid-19 prevention health socialization program which is a community servicebased activity to increase knowledge about efforts to break the chain of Covid-19 transmission carried out in Margasari Village, West Balikpapan District, Balikpapan City with service methods in the form of socialization activities and environmental field activities. housing and traders of micro, small and medium enterprises. This community service has received a positive response from the government and high active community participation, and is expected to always comply with the $5 M$ health protocol.
\end{abstract}

Keywords: community service; covid19; health protocols; community participation.

\begin{abstract}
ABSTRAK
Kegiatan sosialisasi kesehatan pencegahan covid 19 merupakan kegiatan pengabdian kepada masyarakat dalam upaya kontribusi kepada masyarakat untuk pemenuhan kebutuhan hidup dan menyelesaikan permasalahan yang dialami masyarakat khususnya dalam pencegahan penularan Covid-19. Kegiatan ini dilaksanakan melalui program Sosialisasi kesehatan pencegahan Covid-19 yang merupakan kegiatan berbasis pengabdian kepada masyarakat untuk meningkatkan pengetahuan tentang upaya memutus mata rantai penularan Covid-19 dilaksanakan di Kelurahan Margasari, Kecamatan Balikpapan Barat Kota Balikpapan dengan metode pengabdian berupa kegiatan sosialisasi dan kegiatan lapangan dilingkungan perumahan dan pedagang usaha mikro kecil dan menengah. Pengabdian kepada masyarakat ini mendapat respon positif pemerintah serta partisipasi aktif masyarakat yang tinggi, dan diharakpan selalu mematuhi protokol kesehatan 5M.
\end{abstract}

Kata Kunci: pengabdian masyarakat; covid19; protokol kesehatan; partisipasi masyrakat.

\section{PENDAHULUAN}

Pengabdian kepada masyarakat merupakan sarana untuk menjembatani dunia pendidikan khususnya pendidikan tinggi dengan masyarakat sebagai stakeholder, dimana perguruan tinggi dihadapkan pada masalah bagaimana agar warga masyarakat dapat mengatasi suatu permasalahan dengan baik dan benar dan 
kontribusi oleh akademisi. Akademisi yang dimaksud adalah Dosen dan Mahasiswa.

Salah satu topik yang sangat hangat dan menjadi permasalahan dunia sekarang adalah masalah wabah virus corona (Covid19). Wabah ini sekarang disebut pandemic karena wabahnya berlangsung lama dengan gejala yang bisa berubah-ubah dan tanpa memandang siapa yang telah terjangkit. Permasalahan penanganan wabah virus corona ini menjadi masalah internasional yang sangan sulit teratasi.

Organisasi Kesehatan Dunia (WHO), melalui Direktur Jenderal Adhanom Ghebreyesus secara resmi mengumumkan Virus Corona ( COVID-19) sebagai Pandemi pada tanggal 11 maret 2020. Pandemic terjadi jika suatu penyakit menular dengan mudah dari manusia ke manusia di berbagai tempat diseluruh dunia. Hingga saat ini jumlah kasus COVID 19 diluar China telah meningkat begitu pesat ini menimbulkan kecemasan bahwa bila tidak dilakukan antisipasi akan menimbulkan masalah yang lebih besar dan mempengaruhi segala sendi kehidupan. Pemerintah Indonesia telah menetapkan kejadian ini melalui keputusan presiden (Keppres) no.11 tahun 2020 tentang penetapan Kedaruratan Kesehatan masyarakat Corona Virus Disease 2019 sebagai jenis penyakit yang menimbulkan kedaruratan kesehatan masyarakat, Pemerintah menetapkan bahwa wajib dilakukan upaya penanggulangan sesuai dengan ketentuan peraturan perundang undangan. Dengan diberlakukannya status Kejadian Luar Biasa pemerintah telah menerapkan berbagai protokol seperti meliburkan sekolah, meliburkan berbagai kantor, menghimbau bekerja, belajar dan beribadah dari rumah, menghimbau untuk menghindari kegiatan yang melibatkan banyak orang. Untuk mendukung upaya pemerintah ini maka masyarakat ikut bertanggung jawab agar selalu proaktif untuk disiplin dalam memproteksi diri sesuai himbauan pemerintah untuk menerapkan disiplin dalam melaksnakan protokol pencegahan penularan COVID-19. (Djalante, dkk, 2020).

Pemerintah Indonesia telah menetapkan kejadian ini melalui keputusan presiden (Keppres) no. 11 tahun 2020 tentang penetapan Kedaruratan Kesehatan Masyarakat Corona Virus Disease 2019.

Adapun himbauan dari pemerintah untuk melakukan pencegahan virus ini maka masyarakat selalu dianjurkan untuk protokol kesehatan 3M yakni memakai masker dengan benar, mencuci tangan dengan sabun dan air mengalir, serta menjaga jarak. Protokol kesehatan 3M saat ini telah mengalami perubahan menjadi 5M. Gerakan 5M yaitu memakai masker, mencuci tangan pakai sabun dan air mengalir, menjaga jarak, menjauhi kerumunan, serta membatasi mobilisasi dan interaksi, Untuk ikut berpartisipasi dalam upaya memutus mata rantai penularan Covid19 dengan meningkatkan pengetahuan masyarakat tentang Covid19, dan upaya mengantisipasi dampak dari penularan Covid19 yang tidak hanya mempengaruhi dari sisi kesehatan namun berdampak pada kehidupan sosial lainnya khususnya bidang ekonomi yang mempengaruhi penghasilan dan pendapatan masyarakat akibat adanya pembatasan sosial, oleh karena itu kami melakukan pengabdian kepada masyarakat di Kelurahan Margasari Kota Balikpapan yang dilaksanakan pada tanggal 09 Februari 2021 sampai dengan 18 Februari 2021. Program kegiatan yang dilakukan adalah bakti sosial lingkungan antar lain berupa pembagian sembako, pembagian masker, penyediaan tempat cuci tangan dan tempat 
sampah, Pemasangan spanduk himbauan, penyemprotan disinfektan dan penyuluhan tentang pentingnya penerapan protokol kesehatan untuk memutus mata rantai

\section{BAHAN DAN METODE}

Beberapa tahap yang dilakukan pada kegiatan pengabdian kepada masyarakat yang dilaksanakan di Kelurahan Margasari Balikpapan meliputi:

\section{Tahap persiapan:}

1. Survey lokasi: meninjau mendatangi secara langsung tempat yang akan diberikan sosialisasi tentang budaya hidup sehat dan cara pencegahan covid-19 dan kegiatan bakti sosial berupa penyerahan seperangkat alat cuci tangan; masker dan sembako, dan kegiatan bakti sosial lainnya berupa penyemprotan di daerah yang terdampak covid-19.

2. Pemantapan, penentuan lokasi dan sasaran

3. Persiapan perlengkapan dan peralatan berupa: materi sosialisasi, bahan-bahan kebersihan, sembako, dan alat penyemprotan beserta alat pelindung diri.

\section{Tahap Pelaksanaan:}

1. Metode ceramah dan diskusi

Metode ceramah dan diskusi digunakan untuk memberikan penjelasan tentang budaya hidup yang sehat serta berinteraksi dengan masyarakat agar masyarakat sebagai peserta dapat memahami dengan

\section{HASIL DAN PEMBAHASAN}

Kegiatan Sosialisasi kesehatan yang dilakukan pada Kelurahan Margasari Balikpapanpada saat pandemi covid-19 ini masih berlangsung, sehingga dalam pelaksanaannya selalu mematuhi protokol penyebaran covid-19 yang diharapkan menjadi salah satu upaya kita untuk menahan laju penyebaran virus.

benar tahapan yang harus dilakukan dalam mencegah dan menangani covid-19.

2. Metode simulasi

Metode ini dilakukan untuk memberikan contoh kepada masyarakat sebagai peserta untuk mempraktekan atau memperagakan apa yang telah disampaikan.

3. Metode bakti sosial

Melakukan kegiatan bakti sosial pemberian langsung berupa:

a. Bahan pencegahan covid-19: berupa masker, sabun cuci tangan, dan hand sanitizer.

b. Bahan sembako untuk menangani sementara konsumsi sehari-hari bagi masyarakat yang terkena dampak covid-19.

c. Penyemprotan disenfektan pada rumah-rumah dan kios-kios pedagang, serta tempat-tempat dilingkungan kelurahan Margasari Kota Balikpapan.

d. Pemasangan penempelan stiker-stiker dan atau poster serta spanduk tentang pencegahan covid-19 di tempattempat yang strategis dilingkungan kelurahan Margasari Kota Balikpapan.

kesehatan 5M. Adapun hasil dari kegiatan ini adalah sebagai berikut:

\section{Sosialisasi.}

Sosialisasi dilaksanakan di pelataran rumah warga Kelurahan Margasari Balikpapan, karena kondisi pada saat pandemic covid-19 
ini maka warga yang menghadiri juga dibatasi hanya terdiri dari beberapa perwakilan warga dan beberapa warga yang terdampak covid19 serta Ketua Rukun Tetangga setempat dan Lurah Margasari.

Materi yang diberikan pada sosialisasi tentang budaya hidup sehat dan bersih antara lain:

a. Cukupi kebutuhan air minum bening.

Untuk membantu tubuh agar tidak cepat dehidrasi dan dapat meningkatkan kesehatan tubuh setidaknya minum 8 gelas sehari.

b. Perbanyak asupan makanan bergizi. Dengan menerapkan pola makan sehat dan penuh nutrisi serta bergizi. Salah satu makanan yang baik untuk daya tahan tubuh adalah makanan kaya vitamin $\mathrm{C}$ dan vitamin $\mathrm{B}$ kompleks.

c. Olahraga Rutin.

Membiasakan olahraga sebelum melakukan aktivitas harian.

d. Istirahat cukup.

Tidur dapat membantu memaksimalkan metabolisme dan menjaga daya tahan tubuh. Tidur minimal 7-8 jam setiap harinya.

e. Konsumsi multivitamin.

Membantu tubuh dalam memenuhi kebutuhan vitamin harian dengan mengkonsumsi multivitamin secara rutin dan teratur, yang mengandung vitamin $\mathrm{C}$ untuk bantu meningkatkan sistem imunitas dan menjaga daya tahan tubuh.

f. Menggunakan masker ketika pergi keluar rumah.

Masker dapat mencegah penyebaran virus dengan melindungi bagian wajah dari droplets seseorang yang mengandung Covid-19.

g. Menerapkan jaga jarak.

Dengan memastikan jaga jarak dan tidak melakukan kontak terlalu dekat dengan orang lain. Menghindari kerumunan ditempat ramai.

h. Mencuci tangan secara rutin.

Selalu cuci tangan dengan sabun dan air mengalir, terutama setelah menyentuh benda yang ada di ruang publik, Jika tidak ada wastafel atau toilet, gunakan hand sanitizer untuk membersihkan tangan, cuci tangan yang benar:

\section{a) Telapak tangan}

Cara cuci tangan yang pertama adalah dengan menggosok kedua telapak tangan. Telapak tangan adalah bagian tubuh pertama yang bertemu dengan benda lain.

b) Telapak dan punggung tangan. Langkah kedua adalah dengan menggosok telapak tangan kiri kepunggung tangan kanan. Hal yangsama berlaku sebaliknya.

c) Kaitkan jari.

Langkah Setelah mencuci telapak dan punggung tangan, bersihkan sela-sela jari, kaitkan jemari dan gosok telapak tangan sampai bersih.

d) Punggung jari.

Langkah selanjutnya membersihkan punggung jari. Gosok punggung jari dengan arah memutar di atas telapak tangan.

e) Jempol

Karena jaraknya yang agak berjauhan dengan jari lain, maka jempol dibersihkan secara terpisah dengan cara menggenggam jempol kanandengan tangan kiri, kemudian gosok dengan arah memutar, hal sama juga berlaku dengan jempol kiri.

f) Kuku

Kuku menjadi tempat bersarangnya kuman. Membersihkanya dengan cara kuncupkan jemari, kemudian 
gosok di telapak tangan. Lebih efektif bila kuku tidak panjang atau sering dipotong. Setelah mencuci tangan dengan sabun, bilas menggunakan air bersih yang mengalir dan keringkan tangan.

i. Membersihkan permukaan benda dengan disinfektan.

Membersihkan barang atau benda yang sering disentuh dengan disenfektan secara rutin seperti gagang pintu, pegangan pada tangga, stop kontak, kantong belanjaan yang sering digunakan dan lain-lain.

\section{Bakti Sosial}

Melakukan kegiatan bakti sosial pemberian langsung Bahan pencegahan covid-19 berupa masker, sabun cuci tangan, dan hand sanitizer. Gambar berikut pemberian masker kepada para pedagang usaha mikro Kecil dan menengah, karena lingkungan Kelurahan Margasari sebagian besar adalah kios pedagang UMKM,

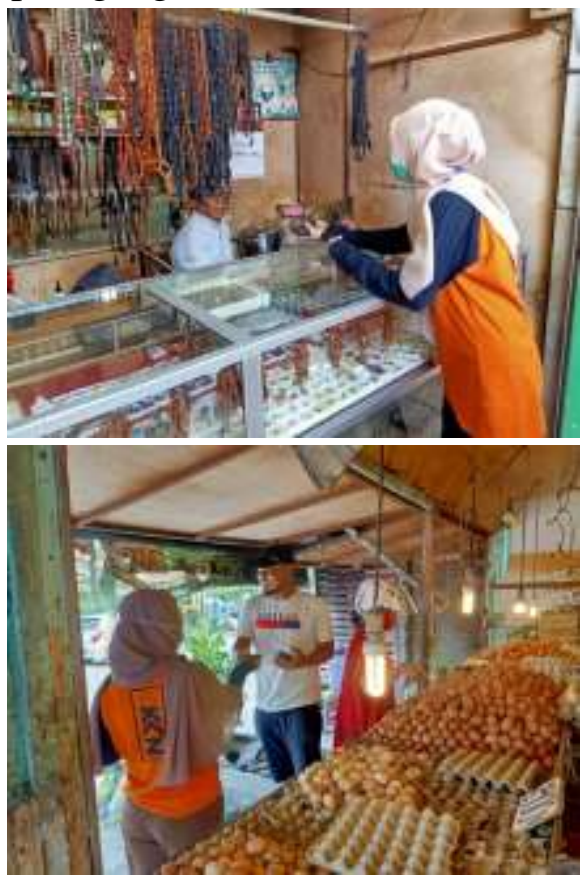

Pemberian bahan sembako untuk menangani sementara konsumsi sehari-hari bagi masyarakat yang terkena dampak covid-19. Gambar berikut menunjukkan kegiatan penyerahan sembako.

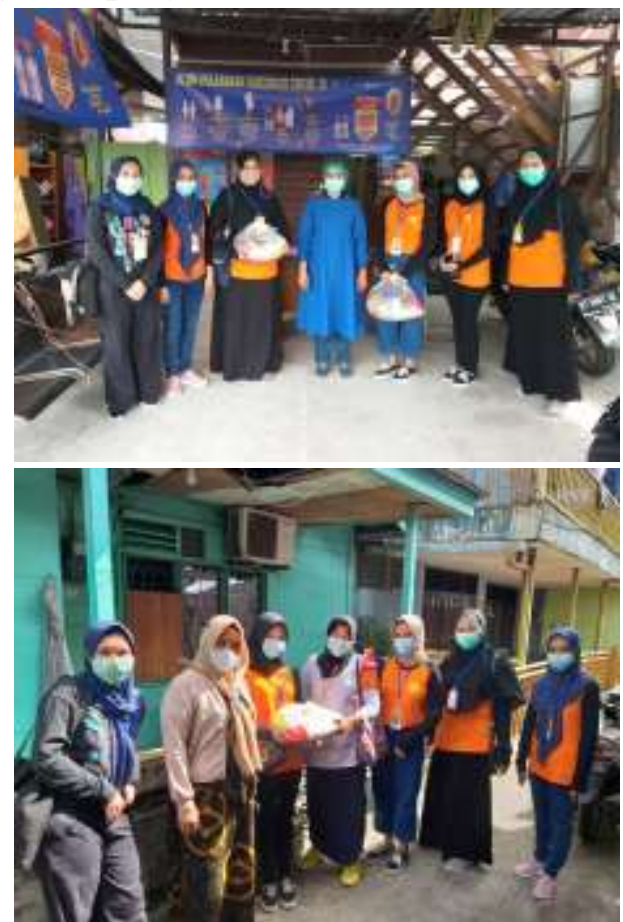

Penyemprotan disenfektan pada rumahrumah, kioskios pedagang, dan tempattempat dilingkungan Kelurahan Margasari Kota Balikpapan. Gambar berikut memperlihatkan kegiatan penyemprotan.

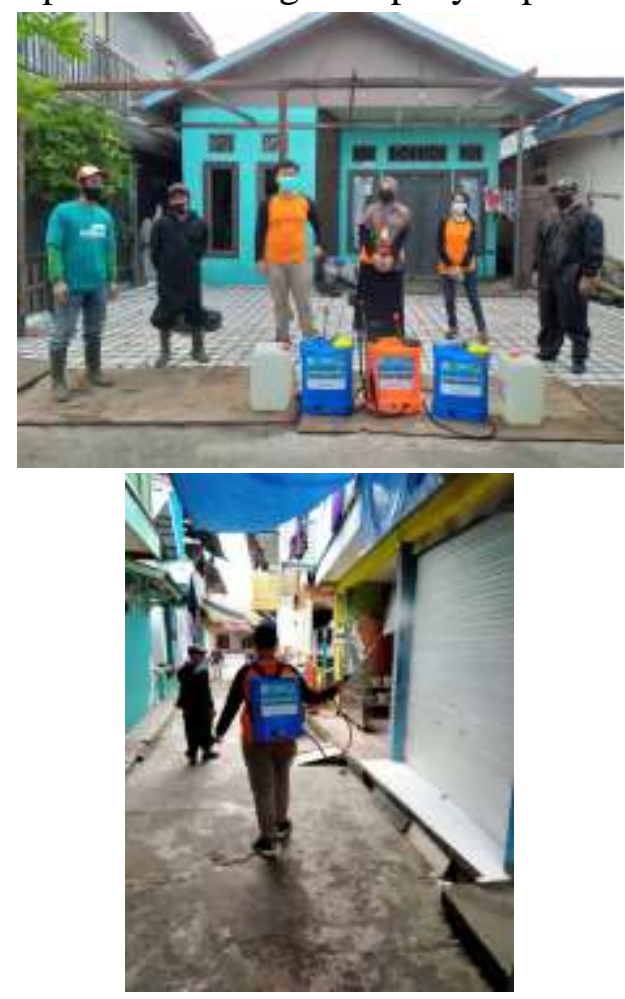


Pemasangan penempelan stiker-stiker dan atau poster serta spanduk mengenai pencegahan covid-19 di tempat-tempat yang strategis di lingkungan Kelurahan Margasari Kota Balikpapan.

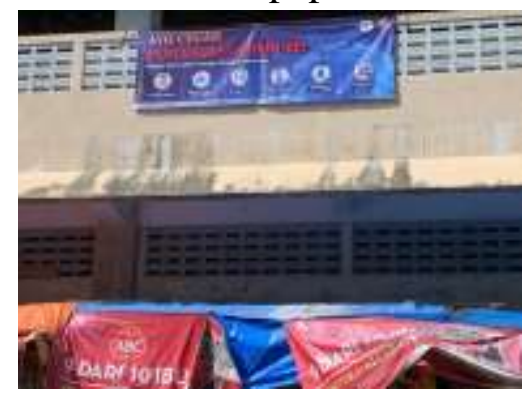

\section{KESIMPULAN}

Kegiatan sosialiasasi kesehatan dan bakti sosial Covid19 telah dilaksanakan sesuai dengan rencana berkat kerjasama dan dukungan dari berbagai pihak, Pihak Kecamatan Balikpapan Barat dan Kelurahan Margasari, Puskesmas dan masyarakat umum. Kegiatan pengabdian masyarakat ini dalam bentuk penyuluhan tentang upaya memutus mata rantai penularan Covid19 yang dilakukan dengan pembagian masker, pembagian sabun cuci tangan dan penyemprotan disinfektan, memberikan pemahaman dan kesadaran mentaati protokol kesehatan 5M, dimana membantu para masyarakat umum menambah wawasan mereka mengenai kesehatan diri yang diharapkan akan membentuk perilaku positif dan menjadikan sebagai suatu perilaku sehat yang bisa menjadi model bagi keluarga dan masyarakat.

Pemerintah kelurahan dan masyarakat Kelurahan Margasari sangat antusias menyambut dengan baik kegiatan ini, masyarakat merespon posistif dari kegiatan pengabdian masyarakat apalagi

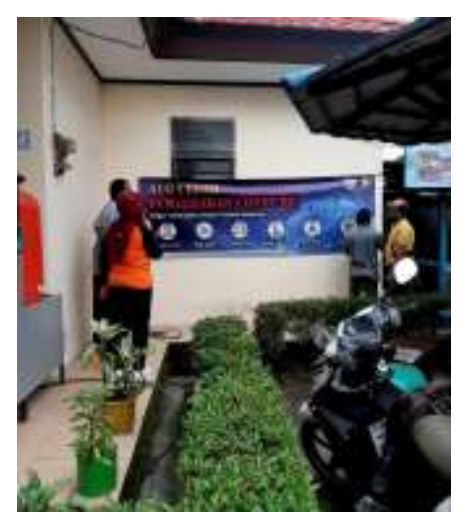

dengan pemberian masker gratis, sembako serta penyemprotaan disenfektan yang bertujuan untuk kesehatan lingkungan.

\section{Ucapan Terima Kasih}

Sebagai penyelenggara kegiatan pengabdian kepada masyarakat mengucapkan banyak terima kasih kepada semua pihak yang telah berpartisipasi dalam membantu kelancaran kegiatan ini, para pihak Kelurahan Margasari terutama Bapak Lurah beserta Staf, Ketua Rukun Tetangga, Puskesmas yang mendampingi selama kegiatan berlangsung, sumbangan masker dan sembako dari pihak donator.dan peran serta masyarakat. Harapannya kegiatan ini memberikan manfaat bagi masyarakat dan kita semua serta memberi kontribusi nyata dan positif dalam upaya memutus mata rantai penularan Virus Corona19. Harapan kita semua sebagai masyarakat Indonesia dan bagian dari masyarakat Dunia dimana pansedik Covid19 bisa berlalu, dan kehidupan kembali normal seperti sedia kala. Aamiin. 


\section{DAFTAR PUSTAKA}

Cucinotta, D., \& Vanelli M. (2020). WHO declares COVID-19 a pandemic. Acta bio-medica Atenei Parm

Djalante R, Lassa J, Setiamarga D, Sudjatma A, Indrawan M. (2020). Review and analysis of current responses to COVID-19 in Indonesia: Period of January to March 2020.

Handayani, D., Hadi, D. R., Isbaniah, F., Burhan, E., \& Agustin H. (2019). Corona Virus Disease. Jurnal Respirologi Indonesia, 40(2), 119129.

Ha BTT, Quang LN, Mirzoev T, Tai NT, Thai PQ, Dinh PC. (2020). Combating the COVID-19 epidemic: Experiences from Vietnam. Int $\mathbf{J}$ Environ Res Public Health, 17(9).

Keputusan Presiden (KepPres) no. 11 tahun 2020 tentang penetapan Kedaruratan Kesehatan masyarakat Corona Virus Disease 2019.
Kemenkes RI (2020). Pedoman Pencegahan dan Pengendalian Coronavirus Disease (COVID-19). 2020.

Notoatmodjo S. (2010). Promosi Kesehatan Masyarakat Teori dan Aplikasi. Jakarta.

Saputra, M., Arsyi, M., Nurhanifah, N., Octavia, S. N., \& Pratomo, H. (2020). Evaluasi Pedoman Penanganan Cepat Medis dan Kesehatan Masyarakat tentang Coronavirus Disease (COVID-19) di Indonesia. Jurnal Ilmiah Ilmu Keperawatan Indonesia, 10(02), 8-17.

S.N., \& Pratomo H. (2020). Evaluasi Pedoman Penanganan Cepat Medis dan Kesehatan Masyarakat tentang Coronavirus Disease (COVID-19) di Indonesia. Ilmu Ilmu Keperawatan Indonesia 10(02), 8-17.

Wawan \& Dewi A. Pengetahuan, Sikap dan Perilaku Manusia. Yogyakarta. 